\title{
Judicial Activism: A Catalyst to Facilitate Sustainable Abstraction of Groundwater Resources of Bangladesh?
}

\author{
Mohammad Sohidul Islam \\ The University of Melbourne, Melbourne, Australia,mohammadi2@student.unimelb.edu.au
}

\begin{abstract}
Unsustainable groundwater abstraction is now an acknowledged problem in Bangladesh. Current water laws, policies, and institutions are widely recognized to have failed in addressing this problem effectively and efficiently. Moreover, the relevant laws and policies are themselves defective and deficient in controlling the free-style extraction of this precious resource, and compliance is very weak. The institutions responsible for enforcing the legal regulation of groundwater abstraction are also weak, fragmented and patchy. Against this backdrop, this paper investigates whether judicial activism could be one of the avenues to promote the sustainable abstraction of groundwater resources of Bangladesh. The Supreme Court of Bangladesh could be a catalyst in facilitating, though not ensuring, the sustainable abstraction of groundwater resources, not least it could declare laws as well as promote compliance and enforcement by applying its unique judicial activism tool. The Court has made a laudable contribution to the protection of the environment. Despite the intrinsic connectivity of water (both surface and ground) with environment, Court's activism in relation to this resource is very poor and limited, and this is more true in relation to the protection of groundwater resources. In fact, till date the Court has not explicitly dealt with the groundwater depletion issue, and as such judicial activism has not found its way to tackle this menace.
\end{abstract}

KEYWORDS: abstraction, compliance, court, groundwater, judicial activism, laws, policies, unsustainable

\section{Introduction}

The role of the judiciary in a changing society has invited both criticism and accolades from scholars. Some have vehemently opposed the Court's rise while others have highlighted its role in the achievement of social justice (Khosla 2009, 55). Despite a rich vein of criticism (Rosenberg 2008), judicial activism, most notably in South Asia, has gained momentum in changing society due to the failure of the representative institutions. In this region, over the years, the court has strongly voiced for the disadvantaged people, it has placed itself as the bulwark against oppression and tyranny, it has demonstrated itself to be impartial, principled, and capable of achieving results.

Mindful of the potential of the modern judiciary, the framers of the Constitution of the People's Republic of Bangladesh (hereafter 'Bangladesh Constitution') contemplated a robust judiciary with a view to realising a socialist society. Constitutionally, the Supreme Court of Bangladesh [the Supreme Court, the highest Court of the country, consists of the Appellate Division (hereafter the 'AD') and the High Court Division (hereafter the 'HCD')] is the guardian of the constitution and is fully independent in discharging its duties. It has the authority to command compliance with its decisions and orders. This Court is given the power of judicial review by virtue of which it could not only review the State actions to ensure that it did not transgress any provision of the Constitution or the laws of the land, but also could declare any law null and void for being inconsistent with any provision of the Constitution. In other words, the Supreme Court of Bangladesh has the scope to use its judicial activism to purge the society of evils and injustices (Bangladesh Constitution, arts 94, 96, 102, 108, 109, 112).

Initially, the Court displayed its conservative attitude by pursuing a quite restricted jurisprudential path and refused to look beyond the texts of the law (Hoque 2006, 399-400). However, with the advent of the concept of human rights, social justice, environmental justice etc. the Court began to flex its muscle to dispel injustice from the society. The Court began to realise its onerous duty to bring about a social change by applying its constitutionally mandated judicial power. As explored below, the Court has made a laudable contribution to the protection of environment. The Court, however, has lagged behind in using its judicial activism tool to ensure sustainable abstraction of groundwater resources in a way as has been expected. It has the unexplored potential under the Bangladesh Constitution to make a greater contribution to prevent the over-extraction of this precious 
resource, not least it has the constitutional power to declare laws which would have binding effect upon all domiciled in Bangladesh (Bangladesh Constitution, art 111).

\section{Judicial activism in Bangladesh}

Before turning to the substantive discussion on judicial activism, it is pertinent to define, in brief, the term 'judicial activism'.

\section{$2.1 \quad$ Understanding judicial activism}

The term 'judicial activism' refers to cases where the court generates a new legal rule which was previously non-existent (Segal 2011,320), that is to say, the activist judges change the prevailing law, supplement their decisions with obiter dicta, attempt to settle questions of social policy or otherwise extend the judicial remit beyond the settlement of specific disputes (Cohn and Kremnitzer 2005, 333-334). In other words, courts are activists when they change the law, overstep their role of dispute resolution, and decide on policy and other broad questions. Courts exercise judicial activism either by judicial review of administrative actions, or by testing the constitutionality of statutes, or by involving in the shaping of public policy.

\subsection{Judicial activism in Bangladesh}

On different occasions the Court remains vigilant to see that administrative actions do not cause public harm. The Court tested and subsequently annulled several legislations by using this tool. The Court, for example, struck down the Contempt of Court Ordinance 2008 as it undermined judicial independence (Md. Shamsul Hoque and Another v Bangladesh 2008). The Court unhesitatingly declared the $5^{\text {th }}, 7^{\text {th }}, 8^{\text {th }}$, $13^{\text {th }}$, and $16^{\text {th }}$ amendments to the constitution unconstitutional. In the $8^{\text {th }}$ amendment case the Court authoritatively developed the "basic structural pillars of the Constitution" principle which was held to be inviolable in all circumstances, and it decisively concluded that the Parliament in no way can change the basic structure of the Constitution by applying its legislative power whatsoever (Anwar Hossain Chowdhury v Bangladesh 1989). In the recently passed $16^{\text {th }}$ amendment case in response to an argument advanced by the Attorney General of Bangladesh that the policy decision is beyond judicial review and as such, the Court should not poke its nose into such kind of decision, the Court aptly replied that it shall not lay its judicial hands off and shall not remain as silent spectator when the policy decision is violative of the fundamental rights, or of any of the provisions of the constitution (Government of Bangladesh and others v Advocate Asaduzzaman Siddiqui and others 2017, 6).

The Court has played and continues to play a significant role in shaping the public policy. Having observed the non-existence of law to effectively and efficiently prevent and punish sexual harassment of women, the Court came up with clear guidelines in the 'nature of law' to be followed by the employers and educational institutions in preventing and suppressing sexual harassment of women until 'effective legislation' is adopted (BNWLA v Bangladesh 2009). The Court developed legal amulet against misuses of arresting power of the police and of the discretion of the magistrates to remand (send back) the arrestees to the police custody (Bangladesh $\mathrm{v}$ Bangladesh Legal Aid and Services Trust 2016).

The foregoing discussions reveal that judicial activism has not only been used to check administrative and legislative actions, it has been extended to shape public policy. As will be examined later, this potential of the Court could be invoked to promote and shape a viable policy to ensure sustainable abstraction of groundwater resources.

\subsection{Judicial activism in relation to the protection of environment}

The Court has extensively used its judicial activism in the protection and preservation of the environment. In the first decision of its kind the Court asserted that right to live in a decent environment is inclusive in the right to life under articles 31 and 32 of the Bangladesh Constitution, and as such, the State is bound to protect the health and longevity of the people living in the country (Dr. Mohiuddin Farooque v Bangladesh and others 1996). Court's intervention largely prevented the air pollution emitting from two stroke threewheeler vehicles. In response to a writ-petition filed by BELA, the Court directed the government to, 
among others, phase out all existing two stroke three-wheeler vehicles, which notoriously polluted Dhaka's air, from the capital city by December 2002 (Dr. Mohiuddin Farooque v Bangladesh and Others 2003).

The foregoing discussions with reference to cases make it crystal clear that judicial activism is, in one way or another, contributing to the change of society. Having said that it is to be recognised that this judicial activism is largely anchored on the Public Interest Litigation (PIL). PIL implies litigation for the protection of interest of the society at large (Karim, Vincents and Rahim 2012). Instead of being instrumental in advancing public interest litigation through judicial activism, Bangladeshi judges have pursued an inward-looking jurisprudential path for quite some time, refusing to go beyond the texts of law (Hoque 2006, 400). Overwhelmingly strong pressure from established legal quarters eventually forced Bangladeshi judges to move beyond restricted legal formalism, and PIL formally won out in 1996 in Dr Mohiuddin Farooque v Bangladesh case. Since this judgment, different NGOs have run many successful PIL cases mainly concerned with the protection of the environment.

However, as will be seen later PIL does have some palpable constraints in stimulating the judicial activism. It may be too late to initiate judicial action based on litigation and as such, justice may be hamstrung. Suo motu jurisprudence may usher justice in such an urgent circumstance. Most importantly, suo motu intervention is more relevant with respect to the protection of groundwater resources given that damage caused to this precious resource by human activities is devastating and almost irreversible (Aeschbach-Hertig and Gleeson 2012).

Suo Motu (Self-initiated) judicial intervention by the Supreme Court, albeit few in number, has added a new horizon to the justice sector of Bangladesh. Such proceeding is initiated by the Court either completely on its own motion or following news reports or in response to letters addressed to it (Hoque 2011, 8). This suo motu jurisprudence has been extended to the protection of environment. Based on the most recent suo motu proceeding the court ordered the demolition of the skyscraper BGMEA building as it was constructed on the natural water bodies which was subsequently affirmed by the AD (President, Bangladesh Garments Manufacturers and Exporters Association (BGMEA) v Government of Bangladesh 2016).

However, suo motu jurisprudence suffers legal uncertainty (Hoque 2003). It is argued that suo motu intervention can only be exercised in case of palpable gross criminal injustice and the Court is not empowered to initiate judicial review actions suo motu under article 102 of the Constitution (Islam 2002, 1-23). To remove this legal uncertainty the Supreme Court of Bangladesh may follow the trail of the Indian Supreme Court to authoritatively pronounce on its authority to issue writs suo motu (Sunil Batra (I) v Delhi Administration 1978). Abuses of public power by the executive or state agencies, insufficient attention in protecting natural resources like groundwater necessitate judicial responses in the form of suo motu judicial action.

\section{Judicial activism in promoting sustainable abstraction of groundwater resources}

The foregoing discussions have explored the judicial activism played by the Supreme Court of Bangladesh to dispel injustices from society ranging from the protection of fundamental rights to the protection of environment. As will be examined later the Court tended to interpret environment widely to include pollution-free water in its components. As noted above, the Court on different occasions extended the meaning of right to life so as to cover a right to enjoy a decent environment, and Court's role in protecting the environment as a whole is heartening. Despite the intrinsic connectivity of water (both surface and ground) with environment (Gupta and Ali 2013), the Court's activism in relation to this resource is very poor and limited, and this is more true in relation to the protection of groundwater resources. In fact, until now the Court has not explicitly dealt with the groundwater depletion issue. It may be attributable to the fact that the environmental groups or other associated agencies have not realised the fact that groundwater table is depleting due to over-extraction, or though they have understood it, they have turned their blind eye to this alarming issue. Additionally, the Court has also failed to problematise this important but overlooked arena of natural resource, and as such judicial activism has not found its way to tackle this problem. The Court, however, has expressed its concern over groundwater quality and has ended up with 
issuing directives to protect this aspect of groundwater. Though this paper does not extend to groundwater quality, yet it is useful to discuss the leading cases on groundwater quality to understand what the approach of the Court with respect to this issue, which could be an indicator for groundwater quantity issue. For example, directing the concerned agency/organisation to produce a report of compliance could be a good strategy to enforce the Court's order in relation to groundwater depletion.

\subsection{Dr. Mohiduddin Farooque v Bangladesh and others (FAP-20 Case): First case to be concerned with water quality}

Dr. Mohiduddin Farooque v Bangladesh and others is the first case where the Court raised the water quality issue, though not elaborately, and connected it to the right to life. In this case His Lordship B.B Roy Choudhury, J. did not shy away to make a direct connection between environmental protection and fundamental rights and more specifically, he noted that the protection and preservation of environment, ecological balance, freedom from pollution of air and water, and sanitary, without which life can hardly be enjoyed, are within the ambit of the Constitution of this country (Dr Mohiuddin Farooque v Bangladesh and others 1997). The Court, however, did not put emphasis on the protection of water resources, nor did it lay down any specific strategy towards the protection of water resources or water quality whatsoever.

\subsection{Dr.Mohiuddin Farooque v Bangladesh and others: Connecting pollution-free water with right to life}

In the case of Dr.Mohiuddin Farooque $v$ Bangladesh and others, the Court expressed its grave concern over the pollution of water being contaminated by the untreated effluents and wastes discharged by the huge number of industries and factories. In this case the Court explained the expression 'life' enshrined in article 32 of the Bangladesh Constitution by providing that it includes everything which is necessary to make it meaningful, and preservation of environment and hygienic condition are of paramount importance for maintenance of health, lack of which may put the 'life' of the citizen at nought. The Court ended with issuing the following directives, among others, to the government-

- it should ensure that the industrial units and the factories adopt adequate and sufficient measures to control pollution and report compliance to the Court thereafter;

- $\quad$ it must ensure that no new industrial units and factories are set up in Bangladesh without first arranging adequate and sufficient measures to control pollution as required under the provisions of the Environment Conservation Act 1995 and the Environment Conservation Rules 1997; and

- the petitioner BELA was put at liberty to bring incidents of violation of any of the provisions of the aforesaid Act and Rules made there under to the notice of the Court.

\subsection{Rabia Bhuiya, MP case: A Step forward to the protection of groundwater quality?}

In fact, the leading case in relation to the groundwater quality is Rabia Bhuiya (2007), MP case. In this case the AD recognised the gravity of the arsenic contamination in Bangladesh and directed the government and other public authorities to comply with the existing laws of the country. The Court came up with specific directives that were to be followed by the responsible government bodies to ensure access to safe drinking water for people at large, free from arsenic. These included:

- $\quad$ taking necessary and effective steps to implement the National Arsenic Mitigation Policy 2004 and the National Action Plan for Arsenic Mitigation;

- framing rules for groundwater management in accordance with the National Policy for Arsenic Mitigation 2004;

- raising mass awareness of the dangers of drinking water from arsenic contaminated tube-wells; and

- $\quad$ providing a yearly report to the court regarding steps taken to implement the Arsenic Policy 2004. 
In summary, these cases suggest the judiciary has significant potential to prevent the depletion of groundwater resources of Bangladesh. True, the judiciary's powers are limited - they cannot physically protect a water body or aquifer - but they can reduce groundwater scarcity by ensuring the public accountability of those in power. Judicial activism yields not only direct results in terms of court-ordered relief, but also encourages social movement strategies towards the sustainable abstraction of groundwater resources (Islam 2014, 9). It is to be noted that if any person violates the order of the Supreme Court, it is empowered to initiate contempt proceedings against the violator (Bangladesh Constitution, art 108). The other ways of enforcing the Court's order include the formation of a committee to monitor whether Court's directives are implemented. Additionally, the Court asks the concerned government agency to make rolling reports of progress or perform specific positive obligations within a fixed time.

Because the latest Water Act has not established any Court which people could approach to seek relief to direct the government or other organisations to stop over-exploitation of groundwater resources, judicial activism by the Supreme Court (empowered by the constitution) remains vital to address activities done, or omitted to be done, by the government or any individuals or organisations in relation to this issue. In other words, as the related laws fall short of preventing the depletion of groundwater resources, and insofar as no court is assigned to deal with this specific issue, judicial activism is a useful tool to promote the sustainable abstraction of this resource.

\section{Problems and prospects of judicial activism in promoting sustainable abstraction of groundwater resources}

Bangladeshi judicial activism encounters certain constraints, presumably stemming from political conditions as well as internal judicial ideologies (Hoque 2011, 138). Politicians often try to influence the decisions of the Court by exerting their political powers and this is possible due to the faulty appointment system of the judges. Power of appointment of a judge in the Supreme Court exclusively lies in the political government (Bangladesh Constitution, arts 48, 95, 98). Arguably, in the recent years political consideration has become a vital factor in appointing a Supreme Court judge (Forum, The Daily Star 2012). In addition to be a person of character and integrity, a judge, in order to handle groundwater issues through judicial action, is required to have sound scientific and technical knowledge (Preston 2008).

Independent Commission like the Judicial Appointments Commission of UK or like the Collegiums consisting of the Chief Justice and four to five senior-most judges of the Supreme Court prevailing in India may be introduced in Bangladesh for the appointment of Supreme Court Judges (Akkas 2004, 201-210). As seen above PIL is one of the most credible responses to effective judicial activism. However, there are some plausible difficulties in Bangladesh with PIL cases. A significant barrier to PIL has, however, been growing efforts by governments to control vocal organisations under the umbrella of NGO regulations (Human Rights Watch 2012). Arrests and imprisonments are common in Bangladesh for environmental activists and human rights defenders (Asian Human Rights Commission 2013). This state of affairs creates risks for the NGOs filing PIL that is against the interests of the government (Karim, Vincents and Rahim 2012, 3). In addition, these organisations have resource constraints, and lack access to legal and scientific literature on the groundwater resources (Karim, Vincents and Rahim 2012, 3).

Moreover, civil societies are weak, unorganised and less rights-centric. Individual lawyers are largely ignorant of PIL's importance and pro-people ramifications (Galanter 1974). The other problem includes the government's indifference to the Court's order. It will often delay action on the grounds that the government does not have sufficient financial and other logistic support (Karim, Vincents and Rahim 2012, 33). The question then arises whether Court's decision could bring about change in the society. Rosenberg doubts the capability of the Court in changing the social scenario (Rosenberg 2008). He came up with the findings that Court's decisions have had no significant direct or indirect effect on the social change. He argued that factors like political efforts wholly separate from the court system bring about considerable changes in the society.

Nevertheless, Court's decisions remain important as they put the government under public and legal pressure to comply with Court's orders in furtherance of protecting natural resources like 
groundwater (Baxi 1993). PIL has immensely helped at least in shaping a pro-people environmental laws and policies in Bangladesh. The prevailing scenario of social deprivation, bad governance, and the violation of constitutional norms in administering state functions, and more specifically the anarchy in groundwater resources is, more or less, an outcome of the lack of public accountability (Hoque 2006, 409).

So far, the Court has performed a commendable job using its judicial activism. As seen above, it crafted guidelines to prevent sexual harassment of women, girls and children at their workplaces, educational institutions, and other public places across the country. As noted above, the AD set out specific guidelines for magistrates and judges and also responsibilities and guidelines for the police in relation to arrest and remand. In the $16^{\text {th }}$ amendment case the Court arduously framed 39 point code of conduct to be observed by the judges of the Supreme Court. The Court did not hesitate to order the demolition of the skyscraper BGMEA building which was constructed on the natural water bodies.

Institutional settings in relation to groundwater resources are very weak, patchy and fragmented, not least they being oblivious of the collaboration and co-operation, work in isolation (WWF 2015, 19). Ministry of Industries, for example, controls and regulates the industry sector of the country which heavily impacts groundwater quantity; but this ministry has not been recognised by the latest Bangladesh Water Act 2013, and as such, it is not included neither in the National Water Resources Council (the highest decision making body for water planning led by the Prime Minister), nor in the Executive Committee. Current laws and policies with respect to groundwater abstraction are not wellcrafted and important issues around its sustainable abstraction have not been addressed by the relevant legislations. The Water Act 2013, for example, has not fixed the maximum amount of water which could be withdrawn by any individual or organisation (Bangladesh Water Act, sec 15). The Act does not impose any restriction on abstraction of water from any privately-owned water source (Bangladesh Water Act, secs 3,26), and uncontrolled abstraction of water from privately owned water source has the potential to significantly affect the overall water resources of the country. The Act has failed to control the installation of shallow and deep tube-well into the ground for abstracting groundwater. Rather by using the ill-defined term 'subject to the lowest safe yield level', it has accorded wholesale license to any person or appropriate authority to sink shallow or deep tube-wells to withdraw groundwater (Bangladesh Water Act, sec 19). The judiciary could potentially fill up these gaps by applying its judicial activism. Furthermore, the Act has not clearly delineated the responsibilities of the concerned agencies/organisations to ensure sustainable abstraction of groundwater resources which could also be dealt with by the Court through this activism. These all suggest that judicial activism could be a promising solution to promote sustainable abstraction of groundwater resources.

\section{Conclusion}

Ronald Dworkin once remarked that 'the courts are the capitals of law's empire, and judges are its princes, not its seers and prophets' (Dworkin 1986, 407). With their wisdom the judges should respond to social needs. The Supreme Court of Bangladesh is empowered to issue directions, orders, and writs by virtue of which it could meet the particular requirements of this country. As seen above, the Court can declare laws to fill up any vacuum in the legal arena. As examined above, this unique power of the Court, with certain limitations, has already been successfully used to the protection of environment of the country. The Court in a very limited way has also applied its judicial activism to protect mainly the quality of groundwater. As noted above, the Court has yet to apply its judicial action in relation to the depletion of this precious resource. Given the enormity of this issue (World Bank 2005) such judicial passivism is undesirable. Public interest litigation (PIL) could be an effective tool to invoke judicial activism. As seen above, the prospect of PIL is largely dependent on the capacity and willingness of the environmental groups. Hence, the concerned groups are needed to be more active and vibrant in bringing more and more suits/cases of this nature. These organisations should conduct more research on groundwater resources to assist the Court to issue directives in relation to the depletion of groundwater resources. The government should execute the Court's order hurriedly without taking recourse to any dilatory tactics. The Court also needs to remain vigilant over 
the proper implementation of its directives. As examined above, suo motu jurisdiction of the Court could be a promising tool in this regard. The Court should cautiously apply this unique tool. It should extend its judicial arm to craft legal amulet to prevent the over-draft of this resource. As the Bangladesh Water Act 2013 is badly crafted in relation to the prevention of groundwater depletion, the Court is the effective tool to emend the repairs. Judicial activism, however, should not be construed to be a governance by the judiciary, rather it is meant, for all intents and purposes, to perform within the limits of the judicial process (Sathe 2001, 106). The media, both print and electronics, should also come forward to stimulate the Court, and the concerned groups should be vociferous when it comes to the over-exploitation of groundwater.

In order to gain the maximum benefit of judicial activism a judge is to be a person of character and integrity. He is required to be independent, fearless, and impartial. As seen above, the current appointment system is faulty. Hence, as suggested above, independent Commission like the Judicial Appointments Commission of UK or like the Collegiums consisting of the Chief Justice and four to five senior-most judges of the Supreme Court prevailing in India may be introduced in Bangladesh for the appointment of Supreme Court Judges. Judicial activism, however, is not a permanent solution to the ever-increasing crisis of groundwater depletion. The executive and the legislature ultimately will have to wake up to respond to this crisis, and essentially the Court push them up to adopt a permanent solution by their proper executive and legislative actions. In short, a proactive judiciary manned with courageous judges assisted by the environmental groups and rights organisations, is indeed, an effective tool to promote sustainable abstraction of Bangladesh groundwater resources.

\section{References}

Aeschbach-Hertig, Werner and Tom Gleeson. 2012. "Regional Strategies for the Accelerating Global Problem of Groundwater Depletion." Nature Geoscience 5(12): 853-61.

Akkas, Sarkar Ali. 2004. "Appointment of Judges: A Key Issue of Judicial Independence." Bond Law Review 16(2): 20010.

Anwar Hossain Chowdhury v Bangladesh (1989) 18 CLC (AD).

Bangladesh, represented by the Secretary, Ministry of Law, Justice and Parliamentary Affairs and others v Bangladesh Legal Aid and Services Trust (BLAST) represented by Dr. Shahdeen Malik and others [2004] AD 53 (24 May 2016).

Bangladesh Water Act 2013 (Act no. 14 of 2013). Bangladesh. http://www.fao.org/faolex/results/details/en/c/LEXFAOC154320/.

Baxi, Upendra. 1985. Courage, Craft, and Contention: The Indian Supreme Court in the Eighties. Bombay : N.M. Tripathi. BNWLA v Bangladesh (2009) 14 BLC (HCD) 694.

Chowdhury, Ahmed Zaker. 2012."Politics of Judicial Appointment” Forum, Vol 6, Iss 4, The Daily Star (online), April. https://archive.thedailystar.net/forum/2012/April/judicial.htm gladesh Water Act 2013 (Bangladesh).

Cohn, Margit and Mordechai Kremnitzer. 2005. "Judicial Activism: A Multidimensional Model." Canadian Journal of Law \& Jurisprudence 18(2): 333-56.

Constitution of the People's Republic of Bangladesh 1972 (Bangladesh).

Dr Mohiuddin Farooque v Bangladesh and others (2003) 55 Dhaka LR (HCD) 69.

Dr Mohiuddin Farooque v Bangladesh and others (1997) 49 Dhaka LR (AD) 1.

Dr Mohiuddin Farooque v Bangladesh and others (1996) 48 Dhaka LR (HCD) 438.

Dworkin, RM. 1986. Law's Empire. Cambridge, Mass. : Belknap Press.

Galanter, Marc. 1974. "Why the "Haves" Come out Ahead: Speculations on the Limits of Legal Change." Law \& Society Review 9(1): 95-160.

Government of Bangladesh and others v Advocate Asaduzzaman Siddiqui and others [2017] AD 6 (3 July 2017).

Gupta, VK and I Ali. 2013. Environmental Water: Advances in Treatment, Remediation and Recycling. Amsterdam: Elsevier.

Hoque, Ridwanul. 2006. "Taking Justice Seriously: Judicial Public Interest and Constitutional Activism in Bangladesh." Contemporary South Asia 15(4): 399-422.

Hoque, Ridwanul. 2011. Judicial Activism in Bangladesh: A Golden Mean Approach. Cambridge Scholars Publishing.

Hoque, Ridwanul. 2003. "Suo motu jurisdiction as a tool of activist judging: A survey of relevant issues and constructing a sensible defence." Chittagong University Journal of Law 8:1-18.

Human Rights Watch. 2012. "Bangladesh: Scrap New Commission to Restrict NGOs, Body is "Smokescreen" for Government to Control Civil Society."

Islam, Mahmudul. Constitutional Law of Bangladesh. Dhaka, Mullick Brothers.

Islam, Mohammad Sohidul. 2014. "A Human Right to Water: Challenges and Opportunities for Ensuring This Right in Bangladesh." Australian Journal of Asian Law 15(2): 1-18. 
Karim, Md Saiful, Okechukwu Benjamin Vincents and Mia Mahmudur Rahim. 2012. "Legal Activism for Ensuring Environmental Justice." Asian Journal of Comparative Law 7(1): 1-44.

Khosla, Madhav. 2009. "Addressing Judicial Activism in the Indian Supreme Court: Towards an Evolved Debate." Hastings International \& Comparative Law Review 32(1): 55-100.

Md. Shamsul Hoque and Another v Bangladesh [2008] HCD (24 July 2008).

President, Bangladesh Garments Manufacturers and Exporters Association (BGMEA) v Government of Bangladesh, represented by the Secretary, Ministry of Housing and Public Works, Bangladesh Secretariat, Dhaka and others [2013] AD 1162 (2 June 2016).

Preston, Brian J. 2008. "Operating an Environment Court: The Experience of the Land and Environment Court of New South Wales." Environmental and Planning Law Journal 25 (6): 385-409.

Rabia Bhuiyan, MP v Ministry of LGRD and others (2007) 59 Dhaka LR (AD) 176.

Rosenberg, Gerald N. 2008. The Hollow Hope : Can Courts Bring about Social Change? Chicago: University of Chicago Press.

Sathe, SP. 2001. "Judicial Activism: The Indian Experience." Washington University Journal of Law \& Policy 6:29-108.

Segal, Zeev. 2011. "Judicial Activism Vis-a-Vis Judicial Restraint: An Israeli Viewpoint." Tulsa Law Review 47: $319-29$. Sunil Batra (I) v Delhi Administration (1978) 4 SCC 494.

World Bank Report. 2005. "Bangladesh Country Water Resources Assistance Strategy." http://documents.worldbank.org/curated/en/657261468205489069/Bangladesh-Country-water-resources-assistancestrategy. 